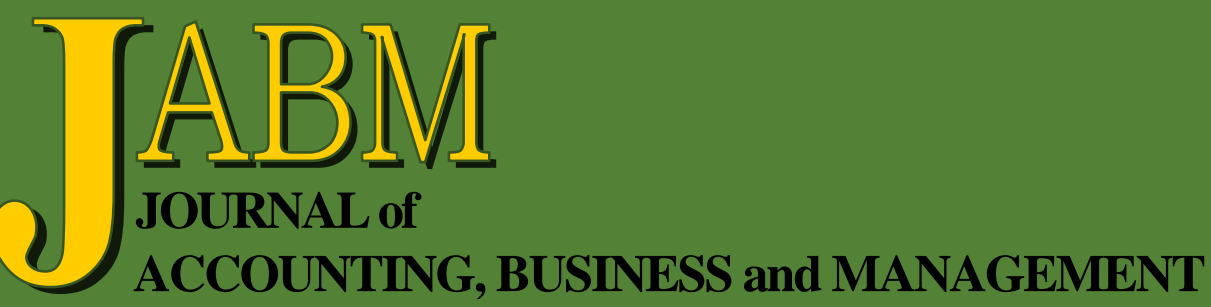

Audit Fee Premium for Industry Specialization: A Developed Country Perspective

Muhammad Shahin Miah

Socio-Demographics Characteristics on Investment Objectives of Individual Investors: Empirical Study in Indonesia

Nevi Danila, Zaiton Ali, Bunyamin and Marlinda D. K.

Dynamic Inflation and Economic Growth Nexus in Bangladesh

Md. Nezum Uddin

Voice of the Customer: Creating Client Centered Cultures in Accounting Firms for Retaining Clients and Increasing Profitability Leisa Gill, Vikkie McCarthy and David Grimmett

Rating the Credit Raters

A. Seetharaman, Nitin Patwa and Shriram Nagarajan 


\title{
Dynamic Inflation and Economic Growth Nexus in Bangladesh
}

\author{
Md. Nezum Uddin*
}

\begin{abstract}
This scholarly article seeks to spotlight the inextricable link between economic expansion and inflation in Bangladesh for the past three decades from 1987 to 2017. The nature of the relationship between these two macroeconomic variables is a boiling topic of research. The data on both the GDP growth and inflation rates supplied by the World Bank have been used to study the nexus. Different relevant tests (DF, ADF, PP and KPSS test) found unit root in the variables, but this problem is disappeared at the first difference. Cointegration tests display the long-run connection between the variables at the period. Max-Eigen value Statistic Trace Statistic expose there may be a second integrating vector. The vector error correction model (VECM) finds short dynamics among inflation and economic development, and the adjustment speed at $39 \%$ and $82 \%$ respectively for the variables-GDP growth rate and inflation. This empirical study has found a significant correlation between inflation and economic growth in Bangladesh during the study period.
\end{abstract}

Keywords: economic growth, inflation, stationary, cointegration, VECM.

\section{INTRODUCTION}

Higher economic growth tandem with mild inflation is an underlying goal of the macroeconomic policies (Hossin, 2015). Economic growth experiences with a positive qualitative, quantitative and structural change which influence fiscal and financial measures as well as the living standard of nations. This trend in the economy follows an upward trajectory (Balcerowicz \& Cojocaru, 2001). Economic growth is an escalation in an economy to make all the finished goods and services in a particular year

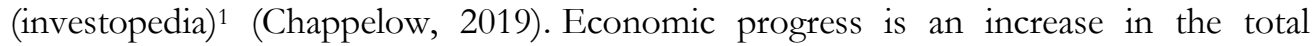
production or size of an economy according to per capita real GDP or GNP (Haller, 2012).

Another moot point is inflation. Inflation fuels an increase in the prices of an economy's product and services at a specific period. If overall price level escalates, local currency fails to buy a bulk of goods and services. The result is obvious. Inflation steadily erodes the currency purchasing capability —a loss of actual value in the internal exchange of money in an economy. According to (Nell, 2000; Mishkin, 2007), the inflation rate is the year-on-year percentage increase in the overall price index. Inflationary impacts can be multiple and simultaneously positive and negative. It has thus been hard to attain such a target due to some of the main reason which affects economic growth. The economic expansion and the rate of inflation are central to the macroeconomic policy. Yet, the direction of the relationship between the price hike and economic development is not specified. Over the last years, researchers have tried

\footnotetext{
* Assistant Professor, Department of Economics \& Banking, International Islamic University Chittagong (IIUC). Phone: +8801818735047. E-mail: ripon.ar@gmail.com.

${ }^{1}$ https://www.investopedia.com/terms/e/economicgrowth.asp.
} 
to investigate the link between these variables and they have come up with differing views. Controversies were aplenty in both theory and empirical findings (Mamo, 2012).

The inflation-economic growth nexus has thus taxed the brains of monetary authorities and policy takers over the globe (Ahmed \& Mortaza, 2010). The vital issue apropos inflation is that it is crucial for economic progress or detrimental triggers a warmed debate both empirically and academically (Ahmed \& Mortaza, 2010). There is no debate in the economic literature on the nexus in question, but a wide-ranging debate is there when discussing the signs of the relationship.

A whole raft of researches on association of growth and inflation have shown the probability of a negative relationship (Fischer \& Modigliani, 1978; De Gregorio, 1993; Fischer, 1993; Barro, 1995; Gylfason \& Herbertsson, 2001; Valdovinos, 2003; and Guerrero, 2006) or a positive relationship (Mundell, 1965; Tobin, 1965; and Mallik \& Chowdhury, 2001).

A sticking point is there that whether inflation is imperative or damaging for economic growth. At first growth rate depends on the speed of capital accumulation which hinges on savings tendency and level of investment. It, therefore, deserves careful study to ascertain whether inflation affects either economic growth or savings and investment (Datta \& Mukhopadhyay, 2011).

Some economists have the identical assessment that inflation spurs economic expansion and thus there is a closer link between the two variables. During an inflationary period, according to neo-classical economists, a time break is exists between an increase in input and output prices, specially a wage lag. This continuous wage lag edges up to the profit margin and this greater profits offer incentives to investable capital for firms. Obviously increased investment is enhanced the output capacity and the higher level of productivity. Inflation also tends to redistribute income for higher-income groups whose income comprises profit partly and partly non-wage income. This type of inflation - an induced redistribution of income-boosts total savings since upper-income groups tend to be savers. A surge in savings raises the supply of investable funds and cuts interest rates that encourage investment and economic expansion. The Phillips curve displays that high inflation poses a low unemployment rate, promoting the economic expansion. Meanwhile, the Tobin effect designates that inflation encourages households to alternate cash for interest-bearing assets, leading to capital accretion which rather spurs growth (Majumder, 2016).

The positive inflation-economic growth relationship is not the only case in point. There is a phrase in economic literature-stagflation. It is a portmanteau word for stagnation and inflation that denotes a situation of high inflation combined with high unemployment and stagnant demand. In the long run, monetarists believe, prices are primarily pushed up by monetary growth with no adverse impact on economic expansion. Inflation plays its part on another macro variable through its effect on capital accretion, investment and export, but it can also deter growth rate.

In the topic under discussion, the Phillips curve formulates a hypothesis that high inflation results in lesser unemployment, meaning that the economic growth is there and vice versa. But in the 1970s, some countries witnessed big boom and those economies also suffered stunted growth at the same time (Rasoolet al., 2014).

The authors are aiming to inspect inflation and growth affiliation from the standpoint of Bangladesh. Majumder (2016) demonstrated this in his seminal work in which he conducted the augmented DF, Granger causality and VECM tests to find the tie between the variables during the 1975-2017 period. Ahmed and Mortaza (2010) used econometric breakdown to get pragmatic links in GDP and CPI in Bangladesh. 


\section{LITERATURE REVIEW}

The literature review attempts to discuss the positive and negative relationships in inflation and economic progress. The inseparable link between these variables has comprehensively been analysed and presented in the economic literature.

De Gregorio (1992) endeavored to trace the convincing records of a rapport in inflation and growth for Latin American nations. The findings exposed an adverse connotation in the variables.

Andrés and Hernando (1999) studied the growth and inflation link in the OECD nation ranging the period from 1960 to 1992. The analysis cited a negative link between two variables. They tried to discover the fundamental equations in two different periods-1961 to 1972 and 1989 to 1992. Demand shocks predominated during the times under review. However, supply shocks were more persistent and significant from 1973 to 1988.

Shitundu and Luvanda (2000) run LTS technique to check the connection between the two major economic variables in Tanzania. Their empirical study suggested that inflation had been harmful to economic expansion in the East African nation.

Nell (2000) attempted to make the cost-benefit analysis of inflationary pressure in South Africa. The country's inflation in the over the 4 decades was separated into 4 episodes. Computed results exhibited that inflation in single digit might benefit growth. In double-digit territory, inflation looks set to inflict costs on slow growth rate.

Khan and Senhadji (2001) surveyed the threshold inflation level in different nations. The edge of inflation is projected at $1 \%$ to $3 \%$ for advanced nation and for developing ones it has found $11 \%$ to $12 \%$.

Valdovinos (2003) has effectively tested the proposition of growth and inflation rate that are negatively interrelated in the long run through applying the Baxter-King Filter method. His hypothesis has been substantiated by the results of the test.

Mubarik and Riazuddin (2005) calculated the inflation threshold level is $9 \%$ in Pakistan using the year-on-year statistics between 1973 and 2000. The results might help Pakistani policymakers provide some clues in setting an optimal inflationary goal.

Saaed (2007) studied the ties of rate of inflation and growth in Kuwait between 1985 and 2005. Empirical result found the existence of long term inverse relation in the variables for the Gulf country.

Erbaykal and Okuyan (2008) have examined the wide-ranging relationship between the two variables in Turkey using substantial data framework covering 1987: 12006: 2 periods through the Bound test established by (Pesaran et al., 2001). Their result exhibited insignificant and long-term relationship, excepting an inverse and shortterm nexus. Again, there have been no causal tie-up from inflation to growth, excepting the Toda-Yamamoto causality test (Toda \& Yamamoto, 1995).

Munir et al. (2009) have surveyed inflation threshold impact on GDP growth in Malaysia for the 1970-2005 periods. The estimated threshold inflation rate found 3.89 percent and above which inflation significantly retards GDP.

Chimobi (2010) attempted to ascertain the inflation-economic growth affiliation in Nigeria from 1970 to 2005. Assessed result found no cointegrating connection in the variables and inflation causes the economic growth not vice versa.

Ayyoub et al. (2011) sought to study the impact of wayward inflation on the GDP growth in Pakistan from 1972 to 2010. The findings of the survey showed the galloping inflation was detrimental to Pakistan's GDP growth after a certain threshold level (7.0\%). Fakhri (2011) studied the prospect of inflation threshold effects on growth 
between the period 2000 and 2009 in the Azerbaijani economy. Estimated result found a non-linear link between the two variables and the threshold inflation is found $13 \%$.

Vinayagathasan (2013) tried to calculate the inflation threshold for the continent of Asia through the dynamic panel threshold analysis during the period from 1980 to 2009. The threshold level of inflation was found at $5.43 \%$ (approximately). Inflation retards economic expansion when it goes over $5.43 \%$. But it has no impact below this level.

Aydin et al. (2016) endeavored to look into the inflationary impact on economic growth for five Turkic republics- Kazakhstan, Azerbaijan, Kyrgyzstan, Turkmenistan and Uzbekistan - through the threshold panel data analysis. Empirical findings indicated a non-linear connection in inflation and growth. Positive impact had been found on economic growth if inflation below $7.97 \%$ and negative impact above this percentage.

Despite the fact that inflationary pressure and economic expansion are vital phenomena for researchers, a small number of studies and analyses have been done and are available in the context of Bangladesh as a fast-growing economy. This article is thus an attempt to discuss the crucial issue of the nexus of these variables in Bangladesh.

Ahmed and Mortaza (2010) made an experimental study on the association between real GDP and inflation ranging from 1980 to 2005 in Bangladesh. Experimental evidence showed a long term adverse association in CPI and GDP. Their estimated result is exhibited $6 \%$ threshold inflation above which inflation adversely affects the economy.

Hossain et al. (2012) launched an investigation to find out a liaison in inflation and growth in Bangladesh ranging from 1978 to 2010. They didn't found any cointegration but a unidirectional causality has been observed from inflation to economic growth.

Younus (2012) wanted to check inflationary growth link in Bangladesh for the period between 1976 and 2012.The results credibly demonstrated that inflationgrowth peer was non-linear and inflation threshold is found $7-8 \%$.

Rahman (2014) tried to explore the underlying connection of economic growth with inflation, trade openness and remittance in Bangladesh from 1976 to 2011. Estimated result found that economic expansion is inversely motivated by inflation but positive with remittance and no link between open trade and growth.

Meanwhile, Hossin (2015) in his study used real GDP and GDP deflator to assess the linkage between the two essential variables-inflation and economic expansion. The results of his empirical work suggested a negative correlation between the variables.

Majumder (2016) ran an investigation into the positive and negative ties of inflation and growth ranging the period between 1975 and 2013. He found a substantial long term positive attachment in inflation and growth.

Sumon and Miyan (2017) initiated to probe the ties in growth and inflation and along with the inflation threshold in Bangladesh for the period from 1986 to 2016. Investigators confirmed a definite link between variables. Inflation adjusts roughly at the speed of $79 \%$ per annum and the projected inflation threshold level was found to be $8 \%$. This is a vital clue for the policymakers. 


\section{METHODOLOGY AND RESULT ANALYSIS}

This study desires to look into the inflation-economic growth nexus in Bangladesh perspective. The year-on-year GDP and CPI from 1987 to 2017 data have been used as the representative of economic growth and inflation respectively. All data and statistics are collected from the World Bank data series. For simplicity, GDP and CPI are denoted as $\mathrm{Y}$ and $\mathrm{X}$ respectively over the study.

\subsection{Unit Root Test}

This study widely conducts the DF and ADF tests to verify the unit root. The KPSS test is also used for the same purpose under different considerations. The ADF tests fail to discriminate well between stationary and non-stationary data. The series is sensorial to structural breaks where the Phillips-Perron (PP) test gives robust estimates (Mallik \& Chowdhury, 2001). 2015):

The easiest way to test the unit root starts with following model (Wooldridge,

$\mathbf{y}_{\mathbf{t}}=\alpha+\rho_{\mathrm{y}_{\mathrm{t}-1}}+\mathrm{e}_{\mathrm{t}}$, where $\mathrm{t}=1,2,3, \ldots$.

$E\left(e_{t} \mid y_{t-1}, y_{t-2}, \ldots ., y_{0}\right)=0$

$\left\{\mathrm{y}_{\mathrm{t}}\right\}$ follows (1), it has a unit root if, and only if, $\boldsymbol{\rho}=1$. If $\alpha=0$ and $\boldsymbol{\rho}=1,\left\{\mathrm{yt}_{\mathrm{t}}\right\}$ follows a random walk without drift. If $\alpha \neq 0$ and $\boldsymbol{\rho}=1, \mathrm{y}_{\mathrm{t}}$ is a random walk with drift.

Now subtract $\mathbf{y}_{\mathbf{t}-1}$ from both sides of (1)

$\mathrm{y}_{\mathrm{t}}-\mathrm{y}_{\mathrm{t}-1}=\alpha+(\rho-1) \mathrm{y}_{\mathrm{t}-1}+\mathrm{e}_{\mathrm{t}}$

$\Delta \mathbf{y}_{\mathrm{t}}=\alpha+\theta \mathbf{y}_{\mathrm{t}-1}+\mathbf{e}_{\mathrm{t}}$, (define $\theta=\boldsymbol{\rho}-1$ )

Equation (3) is without time trend and a best equation with time trend is

$\Delta \mathbf{y}_{\mathrm{t}}=\alpha+\delta_{\mathrm{t}}+\theta_{\mathrm{y}_{\mathrm{t}-1}}+\mathrm{e}_{\mathrm{t}}$

Unit root is present if $\mathrm{H}_{0}: \theta=0$ against $\mathrm{H}_{0}: \theta<0$. The DF, ADF and PP tests rely on the previous process but there are tests where null hypothesis is $\mathrm{H}_{0}: \theta<0$ against $\mathrm{H}_{1}=0$, but these take a different approach in the KPSS test.

The Table 1 displays the findings of different unit root tests where all the variables are found non-stationary at level, but the variables are found stationary at level one (1).

Table 1

Unit Root Test

\begin{tabular}{|c|c|c|c|c|}
\hline \multicolumn{5}{|c|}{ DF Test (Null hypothesis of unit root) } \\
\hline \multirow[t]{2}{*}{ Variables } & \multicolumn{2}{|c|}{ Level } & \multicolumn{2}{|c|}{ First difference } \\
\hline & c & $(c \& t)$ & $\bar{c}$ & $(c \& t)$ \\
\hline$\overline{L Y}$ & $-1.322955^{*}$ & -1.662470 & $-5.717487 * * *$ & $-6.696734 * * *$ \\
\hline LX & -0.219576 & -2.695365 & $-6.335674 * * *$ & $-7.630146 * * *$ \\
\hline \multicolumn{5}{|c|}{ ADF Test (Null hypothesis of unit root) } \\
\hline \multirow[t]{2}{*}{ Variables } & \multicolumn{2}{|c|}{ Level } & \multicolumn{2}{|c|}{ First difference } \\
\hline & $\mathbf{c}$ & $(c \& t)$ & $\bar{c}$ & $(c \& t)$ \\
\hline$\overline{L Y}$ & -1.840794 & -2.234167 & $-7.094251 * * *$ & $-6.953063^{* * *}$ \\
\hline LX & -2.291832 & -2.805865 & $-8.267408^{* * *}$ & $-8.112182^{* * *}$ \\
\hline \multicolumn{5}{|c|}{ KPSS Test (Null hypothesis of no unit root) } \\
\hline \multirow[t]{2}{*}{ Variables } & \multicolumn{2}{|c|}{ Level } & \multicolumn{2}{|c|}{ First difference } \\
\hline & $\mathbf{c}$ & $(\mathrm{c} \& \mathrm{t})$ & $\mathbf{c}$ & $(\mathrm{c} \& \mathrm{t})$ \\
\hline LY & $0.367646^{*}$ & $0.140401 *$ & 0.262450 & 0.035448 \\
\hline LX & $0.704826^{* *}$ & $0.153448^{* *}$ & 0.052081 & 0.048005 \\
\hline
\end{tabular}

Note: author own calculation using E-Views 9. 


\subsection{Cointegration and Error Correction Mode1}

If regressand and regressor both are non-stationary then regression might be spurious (Damodar, 2004). Since our variables are non-stationary, we have to check whether the regressions are spurious. If they are cointegrated, we can use these for further application or we can say they are not spurious. Granger (1983) is defined cointegration as compose of the events that the linear combination of non-stationary processes may have stationary.

Let us suppose, for example, that we regress $\mathrm{Y}$ on $\mathrm{X}$ and found both are I (1) [i.e. they include a unit root]:

$\mathbf{Y}_{\mathrm{t}}=\beta_{1}+\beta_{2} \mathbf{X}_{\mathrm{t}}+\mathbf{U}_{\mathrm{t}}$

Let us write this as,

$\mathbf{U}_{\mathrm{t}}=\mathbf{Y}_{\mathrm{t}}-\beta_{1}-\beta_{2} \mathbf{X}_{\mathrm{t}}$

Assume we have $\mathrm{U}_{t}$ is stationary at level. What is interesting is that compose of two non-stationary series is stationary. As a result, a regression of $\mathrm{Y}$ on $\mathrm{X}$ would be meaningful, that is not spurious. So, we infer that the series are cointegrated. In economic analysis, if two variables get cointegrated they have a long run association or a balance between them (Damodar, 2004).

Few other techniques are there to test and estimate cointegrating relationships in economic literature. Of the techniques, the maximum-likelihood test procedure of Johansen (Johansen, 1988) and Johansen and Juselius (Johansen \& Juselius, 1990) is the utmost operative as it tests the existence of a $3^{\text {rd }}$ cointegrating vector. This method gives two likelihood ratio tests for cointegrating vectors: (a) maximal eigenvalue test that examines null hypothesis of at least $r$ cointegration vectors against the alternative that there are $r+1$ and (b) trace test of the alternative hypothesis that the number of cointegrating vectors is equal to or less than $r+1$. Table 2 shows Johansen's cointegration test. The trace statistic results demonstrate that null hypothesis of no cointegration $(r=0)$ is rejected at $5 \%$ level of significance which confirms inflationeconomic growth cointegration in Bangladesh. Again the rejection of null hypothesis $r=1$ is indicative of a second integrating vector in said variables. The same result is seen in unrestricted cointegration rank test (using maximum eigenvalue).

Table 2

\section{Lag Selection Criteria}

VAR Lag Order Selection Criteria

Endogenous variables: GDPA INF

Sample: 19872017

Included observations: 27

\begin{tabular}{cccllll}
\hline Lag & LogL & LR & FPE & AIC & SC & HQ \\
\hline 1 & -92.62935 & NA & 4.404028 & 7.157730 & $7.349706^{*}$ & 7.214814 \\
2 & -87.32236 & 9.041544 & $4.013063^{*}$ & $7.060916^{*}$ & 7.444867 & $7.175085^{*}$ \\
3 & -85.86889 & 2.260951 & 4.898234 & 7.249548 & 7.825475 & 7.420801 \\
4 & -84.37722 & 2.099397 & 6.026872 & 7.435349 & 8.203253 & 7.663687 \\
\hline
\end{tabular}

Note: author own calculation using E-Views 9.

* indicates lag order selected by the criterion.

LR = sequential modified LR test statistic (each test at $5.0 \%$ level).

$\mathrm{FPE}=$ Final prediction error.

AIC = Akaike information criterion.

$\mathrm{SC}=$ Schwarz information criterion.

$\mathrm{HQ}=$ Hannan-Quinn information criterion. 
Table 3

Johansen Cointegration Test

\begin{tabular}{lcccc}
\hline Eigen Value & Null & Alternative & Max Eigen Statistic & Trace Statistic \\
\hline 0.421622 & $\mathrm{r}=0$ & $\mathrm{r}>0$ & $15.87831^{* * *}$ & $19.79118^{* * *}$ \\
& & & $(14.26460)$ & $(15.49471)$ \\
0.126220 & $\mathrm{r} \leq 1$ & $\mathrm{r}>1$ & $3.912872^{* * *}$ & $3.912872^{* * *}$ \\
& & & $(3.841466)$ & $(3.841466)$ \\
\hline
\end{tabular}

Note: author own calculation using E-Views 9

Both trace test and max eigenvalue test indicate two cointegrating equations at $5.0 \%$ level of significance. $\left({ }^{* *}\right),\left({ }^{*}\right)$, and $(*)$ indicate the rejection of null hypothesis at $1.0 \%, 5.0 \%$ and $10 \%$ level of significance. (MacKinnon et al., 1999) p-values are used for this test indicate the critical value at $5.0 \%$.

Since the variables are cointegrated, there is the presence of an associated ECM that is specified as follows (Engle \& Granger, 1987):

$$
\begin{aligned}
& \Delta Y t=\emptyset_{10}+\sum_{j=0}^{g} \emptyset_{11} j \Delta X t-j \sum_{i=1}^{q} \emptyset_{12} i \Delta Y t-i+\rho_{1} \mu_{t-1}+\varepsilon_{y t} \ldots \ldots \ldots . . \\
& \Delta X t=\emptyset_{20}+\sum_{j=0}^{g} \emptyset_{21} j \Delta Y t-j+\sum_{i=1}^{q} \emptyset_{22} i \Delta X_{1} t-i+\rho_{2} \mu_{t-1}+\varepsilon_{X t} \ldots . .
\end{aligned}
$$

When $\Delta$ denotes the first difference operator, $\mu_{t-1}$ is the error correction term that measures the deviation of the series from the long-run relationship. The series will get integrated into the long-run equilibrium relationship if $\rho_{i} \geq 0(i=1,2)$. Numbers of lag lengths are shown by $s$ and $q, \varepsilon_{y t}$ and $\varepsilon_{x t}$ are random disturbance terms. In order to relate with a structural ECM, $i$ begins at one and $j$ begins at zero in sequence for the series.

The error correction test is crucial to see whether an economy is in equilibrium in the long run or not. The ECM findings also show short-run dynamics.

Table 4

Vector Error Correction Estimate

\begin{tabular}{lcc}
\hline & D(GDP) & D(CPI) \\
\hline CointEq1 & -0.395341 & 0.821795 \\
& $(0.16570)$ & $(0.43908)$ \\
D(GDPA(-1)) & {$[-2.38583]$} & {$[1.87161]$} \\
& -0.395297 & -0.795575 \\
& $(0.19447)$ & $(0.51530)$ \\
D(GDPA(-2)) & {$[-2.03272]$} & {$[-1.54391]$} \\
& -0.192823 & -0.531377 \\
& $(0.18316)$ & $(0.48535)$ \\
D(INF(-1)) & {$[-1.05274]$} & {$[-1.09484]$} \\
& -0.117574 & -0.051737 \\
D(INF(-2)) & $(0.08994)$ & $(0.23832)$ \\
& {$[-1.30729]$} & {$[-0.21709]$} \\
C & -0.073493 & -0.293573 \\
& $(0.07228)$ & $(0.19152)$ \\
& {$[-1.01681]$} & {$[-1.53284]$} \\
F-statistic & 0.226669 & 0.134821 \\
\hline
\end{tabular}

Note: author own calculation using E-Views 9 
Table 5

Dependent Variable: D(GDPA)

Method: Least Squares (Gauss-Newton/Marquardt steps)

Date: 03/10/19 Time: 12:11

Sample (adjusted): 19902017

Included observations: 28 after adjustments
$\mathrm{D}(\mathrm{GDPA})=\mathrm{C}(1) *(\mathrm{GDPA}(-1)-0.665994410736 * \mathrm{INF}(-1)-1.25069997945)+\mathrm{C}(2) *$ $\mathrm{D}(\mathrm{GDPA}(-1))+\mathrm{C}(3) * \mathrm{D}(\mathrm{GDPA}(-2))+\mathrm{C}(4) * \mathrm{D}(\mathrm{INF}(-1))+\mathrm{C}(5) *$ $\mathrm{D}(\mathrm{INF}(-2))+\mathrm{C}(6)$

\begin{tabular}{lcccc}
\hline & Coefficient & Std. Error & t-Statistic & Prob. \\
\hline C(1) & -0.395341 & 0.165704 & -2.385829 & 0.0261 \\
C(2) & -0.395297 & 0.194467 & -2.032723 & 0.0543 \\
C(3) & -0.192823 & 0.183163 & -1.052739 & 0.3039 \\
C(4) & -0.117574 & 0.089937 & -1.307286 & 0.2046 \\
C(5) & -0.073493 & 0.072278 & -1.016808 & 0.3203 \\
C(6) & 0.226669 & 0.171862 & 1.318896 & 0.2008 \\
\hline R-squared & 0.409096 & Mean dependent var. & 0.158844 \\
Adjusted R-squared & 0.274799 & S.D. dependent var. & 1.020554 \\
S.E. of regression & 0.869091 & Akaike info criterion & 2.744672 \\
Sum squared resid & 16.61702 & Schwarz criterion & 3.030144 \\
Log likelihood & -32.42540 & Hannan-Quinn criterion & 2.831943 \\
Durbin-Watson stat. & 1.476716 & &
\end{tabular}

Note: author own calculation using E-Views 9

The estimated coefficients of the VEC term and the lagged values of the two series are shown in Table 4 and Table 5. C(1) is the residual of one period lag of the cointegrating vector between inflation and growth variables. Its sign is negative and statistically significant. One period lag residual $\mathrm{C}(1)$ have to be found the desired sign and significant at $5 \%$ level. That is present study exhibits; inflation leads the economic expansion in Bangladesh in long-run. Another way a long run causal relationship exists between the variables. Furthermore, about $39 \%$ of disequilibrium is corrected each year through changes in economic growth in Bangladesh. From the VECM results, the estimated 0.82 [first value of the third column in Table 4] shows about $82 \%$ of disequilibrium corrected each year through changes in inflation.

\section{CONCLUSIONS AND RECOMMENDATIONS}

To sum up, the author wants to test the practical tie in growth and inflation in Bangladesh applying data from 1987 to 2017. Cointegration and ECM expose both long-run and short-run dynamics respectively. Adjustment term (-0.39) is statistically significant at $5 \%$ level, suggesting that last year's errors (or deviation from long-run equilibrium) are corrected this year at a convergence speed of $39 \%$. Experimental outcomes show that there is a statistically significant long-term positive association exists in economic growth and inflation for the study period.

\section{REFERENCES}

Ahmed, S., \& Mortaza, M. G. (2010). Inflation and economic growth in Bangladesh: 1981-2005 (pp. 1-19). Working paper series: WP 0604, Policy Analysis Unit (PAU). Research Department, Bangladesh Bank, Dhaka, Bangladesk. Retrieved from www.bangladeshbank.org.bd/research/pau.html. 
Andrés, J., \& Hernando, I. (1999). Does inflation harm economic growth? Evidence from the OECD. In The costs and benefits of price stability (pp. 315-348). NBER Working Paper No. 6062. Issue June 1999. The University of Chicago Press.

Aydın, C., Esen, Ö., \& Bayrak, M. (2016, August 19). Inflation and economic growth: A dynamic panel threshold analysis for Turkish Republics in transition process. Procedia-Social \& Behavioral Sciences, 229, 196-205. Doi: 10.1016/j. sbspro.2016.07.129.

Ayyoub, M., Chaudhry, I. S., \& Farooq, F. (2011, June). Does inflation affect economic growth? The case of Pakistan. Pakistan Journal of Social Sciences (PJSS), 31(1), 51-64.

Balcerowicz, L., \& Cojocaru, D. (2001). Libertate si dezvoltare: Economia pietei libere. Compania. Bucureşti, Romana, A Republicii Moldova.

Barro, R. J. (1995, October). Inflation and economic growth. National Bureau of Economic Research Working Paper No. 5326. Massachusetts Avenue, Cambridge.

Chappelow, J. (2019, April 16). Economic growth. Retrieved from https://www.investopedia.com/terms/e/economicgrowth.asp.

Chimobi, O. P. (2010, June). Inflation and economic growth in Nigeria. Journal of Sustainable Development, 3(2), 159-166.

Damodar, N. G. (2004). Basic econometrics (4th ed.). New York, NY: The McGraw-Hill Company.

Datta, K., \& Mukhopadhyay, C. K. (2011). Relationship between inflation and economic growth in Malaysia - an econometric review (pp. 415-419). Paper presented at the International Conference on Economics \& Finance Research (IPEDR 4). IACSIT Press, Singapore.

De Gregorio, J. (1992). The effects of inflation on economic growth: Lessons from Latin America. European Economic Review, 36(2-3), 417-425.

De Gregorio, J. (1993). Inflation, taxation, and long-run growth. Journal of Monetary Economics, 31(3), 271-298.

Engle, R. F., \& Granger, C. W. (1987, March). Co-integration and error correction: representation, estimation, and testing. Econometrica: Journal of the Econometric Society 55(2), 251-276.

Erbaykal, E., \& Okuyan, H. A. (2008, Oct.). Does inflation depress economic growth? Evidence from Turkey. International Research Journal of Finance \& Economics, 13(17), 40-48.

Fakhri, H. (2011). Relationship between inflation and economic growth in Azerbaijani economy: Is there any threshold effect? Asian Journal of Business \& Management Sciences, 1(1), 1-11.

Fischer, S. (1993, December). The role of macroeconomic factors in growth. Journal of Monetary Economics, 32(3), 485-512.

Fischer, S., \& Modigliani, F. (1978). Towards an understanding of the real effects and costs of inflation. Review of World Economics, 114(4), 810-833.

Granger, C. W. J. (1983). Co-integrated variables and error-correcting models. UCSD Discussion Paper 83-13A. Department of Economics, University of California at San Diego

Guerrero, F. (2006). Does inflation cause poor long-term growth performance? Japan \& The World Economy, 18(1), 72-89.

Gylfason, T., \& Herbertsson, T. T. (2001). Does inflation matter for growth? Japan \& The World Economy, 13(4), 405-428.

Haller, A.-P. (2012). Concepts of economic growth and development. Challenges of crisis and of knowledge. Economy Transdisciplinarity Cognition, 15(1), 66-77. 
Hossain, M. E., Ghosh, B. C., \& Islam, M. K. (2012, Oct.). Inflation and economic growth in Bangladesh. Researchers World, 3(4), 85-92.

Hossin, M. S. (2015). The relationship between inflation and economic growth of Bangladesh: An empirical analysis from 1961 to 2013. International Journal of Economics, Finance \& Management Sciences, 3(5), 426-434.

Johansen, S. (1988). Statistical analysis of cointegration vectors. Journal of Economic Dynamics \& Control, 12(2-3), 231-254.

Johansen, S., \& Juselius, K. (1990). Maximum likelihood estimation and inference on cointegration-with applications to the demand for money. Oxford Bulletin of Economics \& Statistics, 52(2), 169-210.

Khan, M. S., \& Senhadji, A. S. (2001). Threshold effects in the relationship between inflation and growth. IMF Staff papers, 48(1), 1-21.

MacKinnon, J. G., Haug, A. A., \& Michelis, L. (1999). Numerical distribution functions of likelihood ratio tests for cointegration. Journal of Applied Econometrics, 14(5), 563-577.

Majumder, S. C. (2016). Inflation and its impacts on economic growth of Bangladesh. American Journal of Marketing Research, 2(1), 17-26.

Mallik, G., \& Chowdhury, A. (2001). Inflation and economic growth: Evidence from four south Asian countries. Asia-Pacific Development Journal, 8(1), 123-135.

Mamo, F. T. (2012). Economic growth and inflation: A panel data analysis (pp. 1-44). Master Programme, Thesis, Department of Social Sciences, Sodertorns University, Stockholm.

Mishkin, F. S. (2007). The economics of money, banking, and financial markets ( $8^{\text {th }}$ ed.). New York: Pearson Education/The Addison-Wesley.

Mubarik, Y. A. (2005). Inflation and growth: An estimate of the threshold level of inflation in Pakistan. SBP-Research Bulletin, 1(1), 35-44.

Mundell, R. A. (1965). Growth, stability, and inflationary finance. Journal of Political Economy, 73(2), 97-109.

Munir, Q., Mansur, K., \& Furuoka, F. (2009). Inflation and economic growth in Malaysia: A threshold regression approach. ASE AN Economic Bulletin, 26(2), 180193.

Nell, K. S. (2000). Is low inflation and precondition for faster growth? The case of South Africa (No. 00,11, pp. 1-28). Discussion Paper. Canterbury: University of Kent, Department of Economics.

Pesaran, M. H., Shin, Y., \& Smith, R. J. (2001). Bounds testing approaches to the analysis of level relationships. Journal of Applied Econometrics, 16(3), 289-326.

Rahman, Z. (2014). The link between remittances and economic growth: Empirical evidence from Bangladesh. International Journal of Social \& Economic Research, 4(2), 140-159.

Rasool, S. A., Raashid, M., Raja, M. U., \& Kausar, J. (2014, September). Inflation and economic growth: Empirical evidence from Pakistan. Journal of South Asian Development, 3(3), 99-107.

Saaed, A. A. J. (2007). Inflation and economic growth in Kuwait: 1985-2005 - Evidence from co-integration and error correction model. Applied Econometrics \& International Development, 7(1), 143-155.

Shitundu, J. L., \& Luvanda, E. G. (2000). The effect of inflation on economic growth in Tanzania. African Journal of Finance \& Management, 9(1), 70-77. 
Sumon, K. K., \& Miyan, M. S. (2017). In flation and economic growth: An empirical evidence of Bangladesh (1986-2016). International Journal of Economics \& Financial Issues, 7(5), 454-464.

Tobin, J. (1965, October). Money and economic growth. Econometrica, 33(4), 671-684. Https://doi.org/10.2307/1910352.

Toda, H. Y., \& Yamamoto, T. (1995). Statistical inference in vector autoregressions with possibly integrated processes. Journal of Econometrics, 66(1-2), 225-250.

Valdovinos, C. G. F. (2003). Inflation and economic growth in the long run. Economics Letters, 80(2), 167-173.

Vinayagathasan, T. (2013). Inflation and economic growth: A dynamic panel threshold analysis for Asian economies. Journal of Asian Economics, 26(C), 31-41.

Wooldridge, J. M. (2015). Introductory econometrics: A modern approach (6 ${ }^{\text {th }}$ ed.). Boston, USA: Cengange Learning, 20 Channel Center Street.

Younus, S. (2012). Estimating growth-inflation trade-off threshold in Bangladesh (pp. 1-16). Working paper. Policy Analysis Unit (PAU), Research Department, Bangladesh Bank, Bangladesh. 